\title{
Ammonia emissions from dairy production in Wisconsin ${ }^{1}$
}

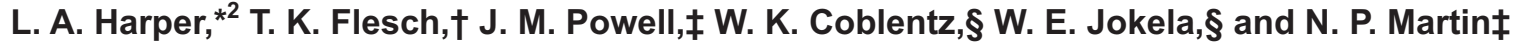 \\ *Department of Poultry Science, University of Georgia, Athens 30602 \\ †Department of Earth and Atmospheric Sciences, University of Alberta, Edmonton, Alberta, Canada T6G 2E3 \\ ‡Dairy Forage Research Center, USDA-ARS, Madison, 53706 WI \\ §Dairy Forage Research Center, USDA-ARS, Marshfield, 54449 WI
}

\section{ABSTRACT}

Ammonia gas is the only significant basic gas that neutralizes atmospheric acid gases produced from combustion of fossil fuels. This reaction produces an aerosol that is a component of atmospheric haze, is implicated in nitrogen $(\mathrm{N})$ deposition, and may be a potential human health hazard. Because of the potential impact of $\mathrm{NH}_{3}$ emissions, environmentally and economically, the objective of this study was to obtain representative and accurate $\mathrm{NH}_{3}$ emissions data from large dairy farms (>800 cows) in Wisconsin. Ammonia concentrations and climatic measurements were made on 3 dairy farms during winter, summer, and autumn to calculate emissions using an inverse-dispersion analysis technique. These study farms were confinement systems utilizing freestall housing with nearby sand separators and lagoons for waste management. Emissions were calculated from the whole farm including the barns and any waste management components (lagoons and sand separators), and from these components alone when possible. During winter, the lagoons' $\mathrm{NH}_{3}$ emissions were very low and not measurable. During autumn and summer, whole-farm emissions were significantly larger than during winter, with about two-thirds of the total emissions originating from the waste management systems. The mean whole-farm $\mathrm{NH}_{3}$ emissions in winter, autumn, and summer were $1.5,7.5$, and $13.7 \%$ of feed $\mathrm{N}$ inputs emitted as $\mathrm{NH}_{3}-\mathrm{N}$, respectively. Average annual emission comparisons on a unit basis between the 3 farms were similar at 7.0, 7.5, and $8.4 \%$ of input feed $\mathrm{N}$ emitted as $\mathrm{NH}_{3}-\mathrm{N}$, with an annual average for all 3 farms of $7.6 \pm 1.5 \%$. These winter, summer, autumn, and average annual $\mathrm{NH}_{3}$ emissions are considerably smaller than currently used estimates for dairy farms, and smaller than emissions from other types of animalfeeding operations.

\footnotetext{
Received September 26, 2008.

Accepted December 6, 2008.

${ }^{1}$ Listing of source names does not imply endorsement or preferential treatment by the University of Georgia, University of Alberta, or the United States Department of Agriculture.

${ }^{2}$ Corresponding author: lharper@uga.edu
}

Key words: ammonia, emissions, dairy, nitrogen

\section{INTRODUCTION}

Ammonia is the most reduced form of $\mathrm{N}$ and is the only significant basic gas in the atmosphere capable of neutralizing acidic atmospheric gases generated by the burning of fossil fuels. As a result, the reaction between $\mathrm{NH}_{3}$ and acid gases produces ammonium $\left(\mathrm{NH}_{4}{ }^{+}\right)$, a component of atmospheric aerosols, which is found in precipitation deposition (Asman et al., 1998) and has been suspected of having negative effects on human health. Ammonia is difficult to measure because of its chemical and physical properties (Harper, 2005), often resulting in inaccurate estimates of emissions. In some cases, more $\mathrm{NH}_{3}-\mathrm{N}$ has been calculated as lost than as $\mathrm{N}$ entering into the system (Eklund and LaCosse, 1995). Agriculture is an important source of $\mathrm{NH}_{3}$ with about two-thirds of all $\mathrm{NH}_{3}$ emissions estimated to come from agriculture and about one-third of the emissions coming from animal production (Bouwman et al., 1997). Consequently, it is important to obtain good estimates of $\mathrm{NH}_{3}$ emissions from dairy production systems because of increasing concerns about potential regulations or oversight of agricultural operations with respect to gas emissions (Powell et al., 2006). Currently, a full understanding of the impact of confined animal feeding operations (CAFO) and effective means of mitigation are hindered by a lack of information on the magnitude of $\mathrm{NH}_{3}$ emissions across the variety of management systems.

An important purpose of CAFO is to provide a uniform and high-quality product, maximize productivity (e.g., meat, milk, eggs), and assure good animal health and reproduction while maximizing unit efficiency (reduced unit nutrient losses and minimizing land and capital resources). Although production efficiency is increased and unit nutrient losses are reduced, incompletely utilized nutrients from these operations may become concentrated in small geographical areas. Under practical conditions, conversion efficiency of feed $\mathrm{N}$ to output product may range from 20 to $50 \%$ (Harper et al., 2004; Powell et al., 2006), depending on animal 
type and product output. Controlled-chamber studies of $\mathrm{NH}_{3}$ emissions from dairy cows have shown that 1 to $3 \%$ of consumed feed $\mathrm{N}$ was lost as volatile $\mathrm{NH}_{3}$ from a simulated tie-stall dairy barn (Powell et al., 2008a). These studies, although appropriate for evaluating treatment effects, do not accurately simulate a commercial production system and do not evaluate other emission sources within the overall waste-management system. Other studies in a small, experimental dairy farm (Rumburg et al., 2008a) concluded that annual housing emissions from freestall barns were $40 \mathrm{~kg}$ of $\mathrm{NH}_{3} /$ cow per year, thereby representing a loss of $11 \%$ of input feed $\mathrm{N}$, which is identical to losses estimated by the US Environmental Protection Agency (USEPA) in the 2004 National Emission Inventory-Ammonia Emissions from Animal Husbandry Operations (USEPA, 2004). In these same studies Rumburg et al. (2008b) concluded that emissions from the waste-management lagoon was $55 \mathrm{~kg}$ of $\mathrm{NH}_{3} /$ cow per year, representing an additional $15 \%$ of feed $\mathrm{N}$ lost as $\mathrm{NH}_{3}$ (also very close to the $18 \%$ estimated by the USEPA from waste lagoons). Ammonia losses from the application of lagoon effluent to crops in this farm (Rumburg et al., 2006) represented $34 \mathrm{~kg}$ of $\mathrm{NH}_{3} /$ cow per year, or another $9 \%$ of feed $\mathrm{N}$ lost as volatile $\mathrm{NH}_{3}$ (an emission much smaller than the USEPA emission estimate of $28 \%$ ). Total $\mathrm{NH}_{3}$ emissions from this experimental farm represented $35 \%$ of input feed N. There is considerable discrepancy between the reported controlled-chamber and small, experimental-farm studies emissions. Few emissions studies have been conducted on whole-farm commercial production systems. Additional studies are needed to determine if studies in these experimental farms and in this geographical location are representative of commercial farms and for other geographical areas.

Because of the chemical properties of $\mathrm{NH}_{3}$ and the interaction between environmental variables and $\mathrm{NH}_{3}$ emissions, the most appropriate techniques for measurement and calculation of emissions are noninterference techniques (Harper et al., 2000). A relatively new noninterference technique, the backward Lagrangian stochastic analysis (bLS) technology, combined with open-path laser measurement technology has been developed in which whole farms and components of farms can be evaluated (Flesch et al., 2004, 2005a, 2009; Harper et al., 2006). The technique uses a bLS atmospheric dispersion model to calculate the gas emission rate given a downwind concentration measurement. In numerous tracer release experiments, the bLS technique has proven accurate for calculating emissions from surface sources (Appendix, Table A1).

The purpose of this study was to apply the bLS technique to accurately determine $\mathrm{NH}_{3}$ emissions from modern dairy production systems in Wisconsin. Our main objective was to provide whole-farm (barns and waste management) emissions estimates, although where possible, we also attempted to determine component emissions (e.g., barns, lagoons, and sand separators). To calculate representative emissions values, we investigated how dairy emissions change with respect to daily and seasonal cycles and attempted to determine the most important factors influencing emissions.

\section{MATERIALS AND METHODS}

Whole-farm $\mathrm{NH}_{3}$ emissions were measured between December 2006 and November 2007, during autumn, winter, and summer periods. Measurements were made at 3 relatively large CAFO (>800 lactating cows) dairies in Wisconsin. The dairies are located in southcentral, northeast, and east-central Wisconsin, and are designated WI1, WI2, and WI3, respectively. Each farm was visited 3 times (winter, spring, and autumn) with each visit lasting from 10 to $14 \mathrm{~d}$. All dairies used a parlor milking system with cows housed in naturally ventilated, freestall barns (side-wall curtains are raised and lowered to control ventilation). Sand was used for bedding and the manure (and sand) was routinely scraped from the concrete barn floors to a central channel and then moved underground to outdoor storage lagoons. At farm WI1 (Figure 1) the barn waste moved to the lagoons by gravity flow. Farms WI2 and WI3 (Figures 2 and 3) employed a flushing system to move the waste (using recycled lagoon water). These latter 2 farms also had a sand separator channel in which sand is deposited before entering the lagoons, whereupon the sand is then gravity drained and recycled for bedding. The barns, lagoons, and sand separator channels were all considered to be potential sources for $\mathrm{NH}_{3}$ emissions. Upwind measurements of background concentrations on all farms showed there were no upwind sources large enough to affect background (upwind) concentrations.

The winter climate in this geographical area is characterized by cold winters with mean temperatures ranging from -20 to $5^{\circ} \mathrm{C}$ and mild summers with mean temperatures ranging from 18 to $23^{\circ} \mathrm{C}$. Mean annual precipitation is $930 \mathrm{~mm}$, with the largest amounts falling during the summer months (Anonymous, 2008).

\section{Farm Site WI1}

This south-central Wisconsin commercial dairy had about 900 milking animals distributed between 2 barns (Figure 1). Two waste-water lagoons were located south of the barns with one lagoon used to collect milking parlor runoff liquids and the other for collection of solids and separated sand from the freestalls. The surface areas of these lagoons were approximately 4,000 and 

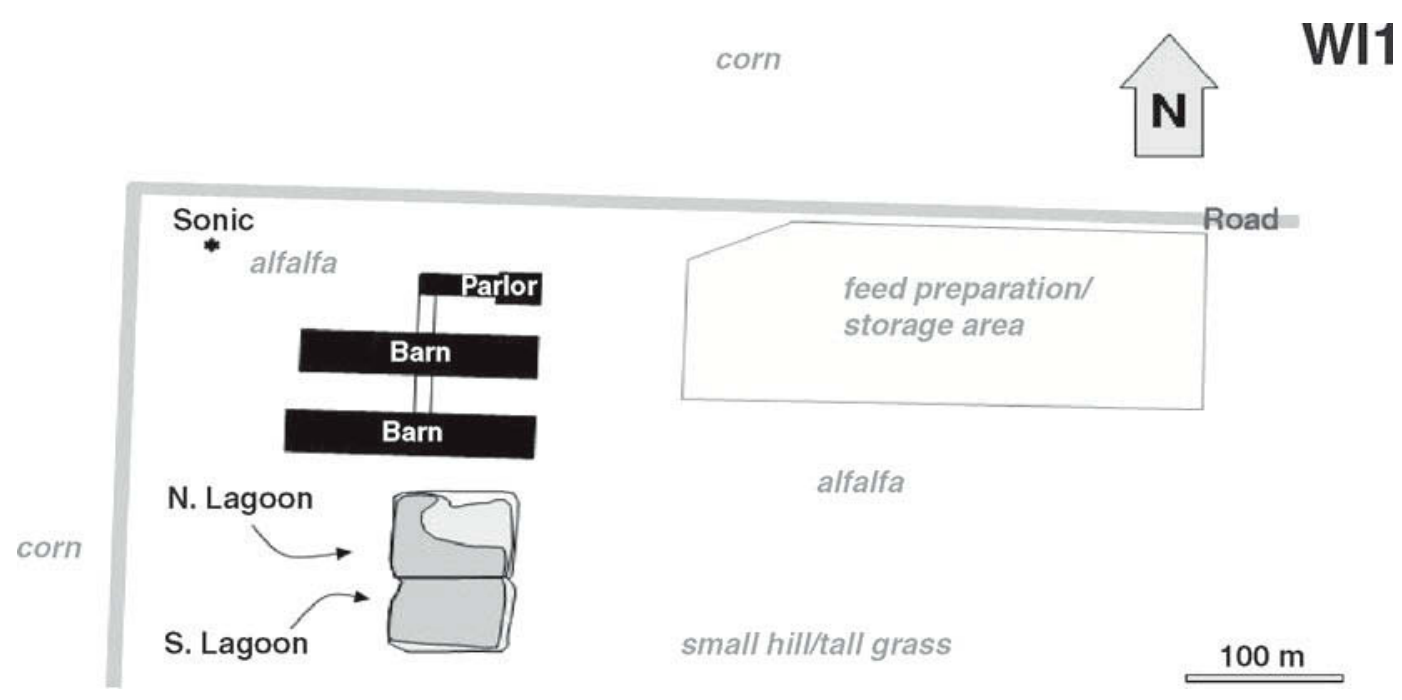

Figure 1. Layout of farm WI1. Surrounding terrain was rolling with crops except for a patch of deciduous trees southeast of the barn/lagoon areas.

$5,000 \mathrm{~m}^{2}$ but they varied in size depending on precipitation and nutrient/solids removal. The surrounding terrain within $200 \mathrm{~m}$ of the main buildings area was open on all sides, except for truck weighing scales and other small structures. In winter, the fields that surrounded the dairy were largely snow covered, whereas during summer they contained alfalfa (Medicago sativa L.) or corn (Zea mays L.) crops.

\section{Farm Site WI2}

Farm site WI2 was a commercial dairy in northeast Wisconsin (Figure 2) that had about 1,400 milking cows and 300 dry cows distributed between 2 barns (the animal numbers increased significantly during the study). South of the barns were 2 adjacent waste-management lagoons $\left(\sim 22,000 \mathrm{~m}^{2}\right)$ and a sand/solids separation channel $\left(\sim 2,400 \mathrm{~m}^{2}\right)$. Both surface areas were slightly variable depending on the amount of waste in the facilities. The lagoons were used to collect barn runoff liquids, and the separation pit was used for collection of solids and separated sand for recycling. The surrounding terrain was open on all sides within $300 \mathrm{~m}$ of the main buildings areas.

\section{Farm Site WI3}

This dairy in east-central Wisconsin (Figure 3) had a capacity of about 1,800 milking cows plus 2,000 dry cows and heifers distributed across 7 barns. East of the barns were 2 lagoons and a sand separation channel. The separation channel $\left(3,200 \mathrm{~m}^{2}\right)$ was used for collection of separated sand for recycling and the lagoons $\left(16,000\right.$ and $\left.14,000 \mathrm{~m}^{2}\right)$ were used for manure and storage. The surrounding terrain was relatively open around the farm, with the exception of a tree lot located southwest of the barns.

\section{Herd Structure and Feed and Manure Management}

At the onset of each farm measurement, a survey was used to gather information on dairy herd structure, feed input, and manure management. The hosts were asked to provide the number of lactating cows, dry cows, and heifers, as well as the type and amount of rations fed during the study. All 3 study farms fed TMR. Representative samples of the TMR and manure storages were taken and frozen immediately $\left(-4^{\circ} \mathrm{C}\right)$ until analyzed. Thawed TMR samples were oven-dried $\left(60^{\circ} \mathrm{C}\right.$, $72 \mathrm{~h}$ ) and ground to pass a 2-mm screen; subsamples were oven-dried $\left(100^{\circ} \mathrm{C}, 24 \mathrm{~h}\right)$ for $\mathrm{DM}$ determination. Analysis for total $\mathrm{N}$ content was by combustion assay (model FP-2000, Leco Corp., St. Joseph, MI). Thawed manure samples were analyzed immediately for total $\mathrm{N}$ using a micro-Kjeldahl assay and $\mathrm{NH}_{4}{ }^{+}-\mathrm{N}$ by distillation (Peters et al., 2003).

\section{Field Measurements}

In the bLS measurement technique we measured $\mathrm{NH}_{3}$ concentration downwind of the emission source of interest whether it be from the whole farm or from one of the component sources. Each concentration time-series, together with wind information, was used to calculate the time-series of emissions using the bLS dispersion model. To account for differences in farm layouts, the variety of emission components within each farm, and seasonal changes in emission sources, we used a variety 


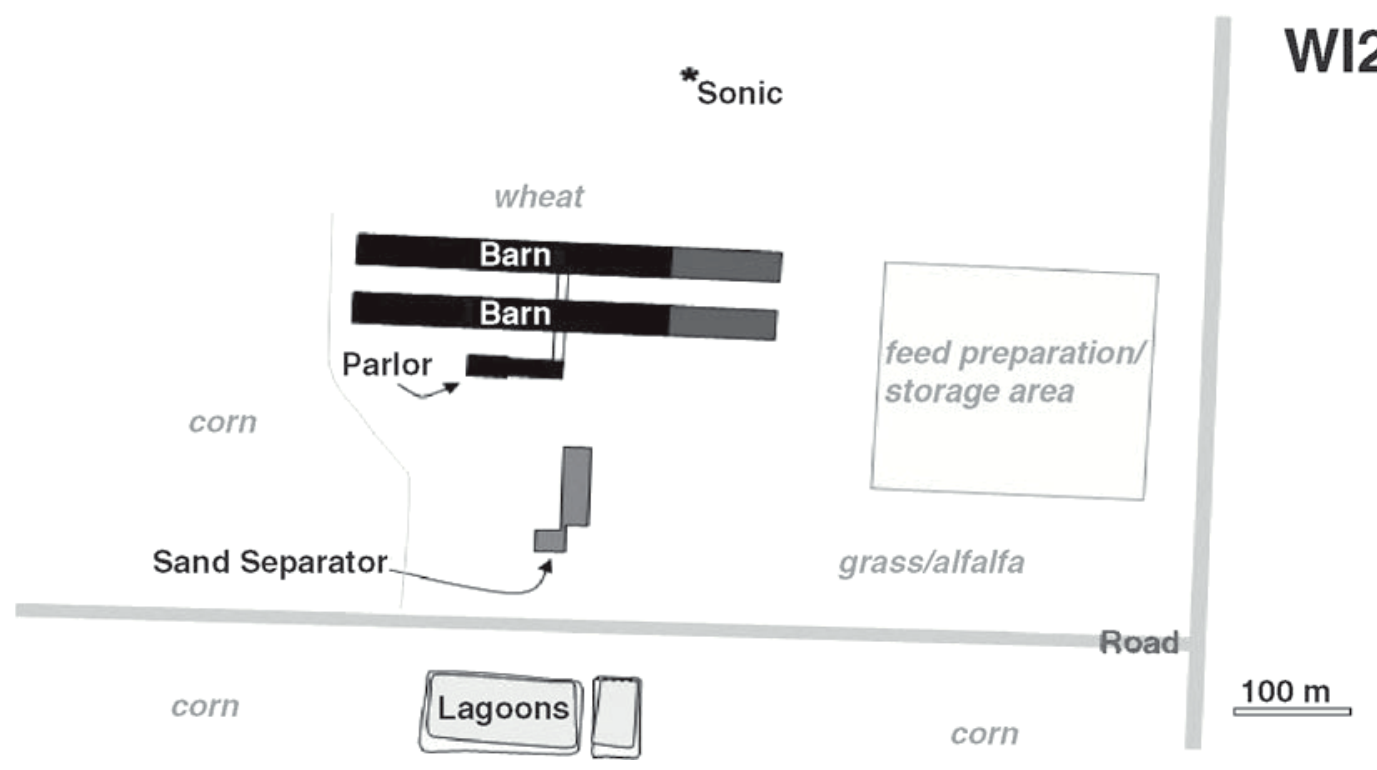

Figure 2. Layout of farm WI2. Surrounding terrain was rolling with crops and no obstructions in any direction except for the feed preparation and storage area.

of measurement strategies (Flesch et al., 2009). However, the measurement principle was always the same; we placed concentration sensors downwind of the emission source and the anemometers in a position to measure the wind experienced by the dispersing $\mathrm{NH}_{3}$ as it moved from the source to the concentration sensor.

Necessary micrometeorological and concentration measurements were made during the winter months from December 2006 to February 2007; summer, during June and July 2007; and autumn, during October and November 2007. Ammonia concentrations were mea- sured using open-path lasers (OPL; GasFinders, Boreal Laser Inc., Edmonton, Canada). The lasers provided line-average concentration (between the laser unit and a retro-reflector) with path lengths ranging from 30 to $1,000 \mathrm{~m}$ depending on the location configuration, and with a height of about $1.5 \mathrm{~m}$ above the crop and $1.0 \mathrm{~m}$ above the lagoon surface. Upwind background concentrations were evaluated periodically from lasers upwind of the emission sources. At our measurement distances, ranging from 700 to $1,000 \mathrm{~m}$, the OPL had a resolution of 0.005 to $0.007 \mathrm{ppm}$ by volume $\left(\mathbf{p p m}_{\mathbf{v}}\right)$

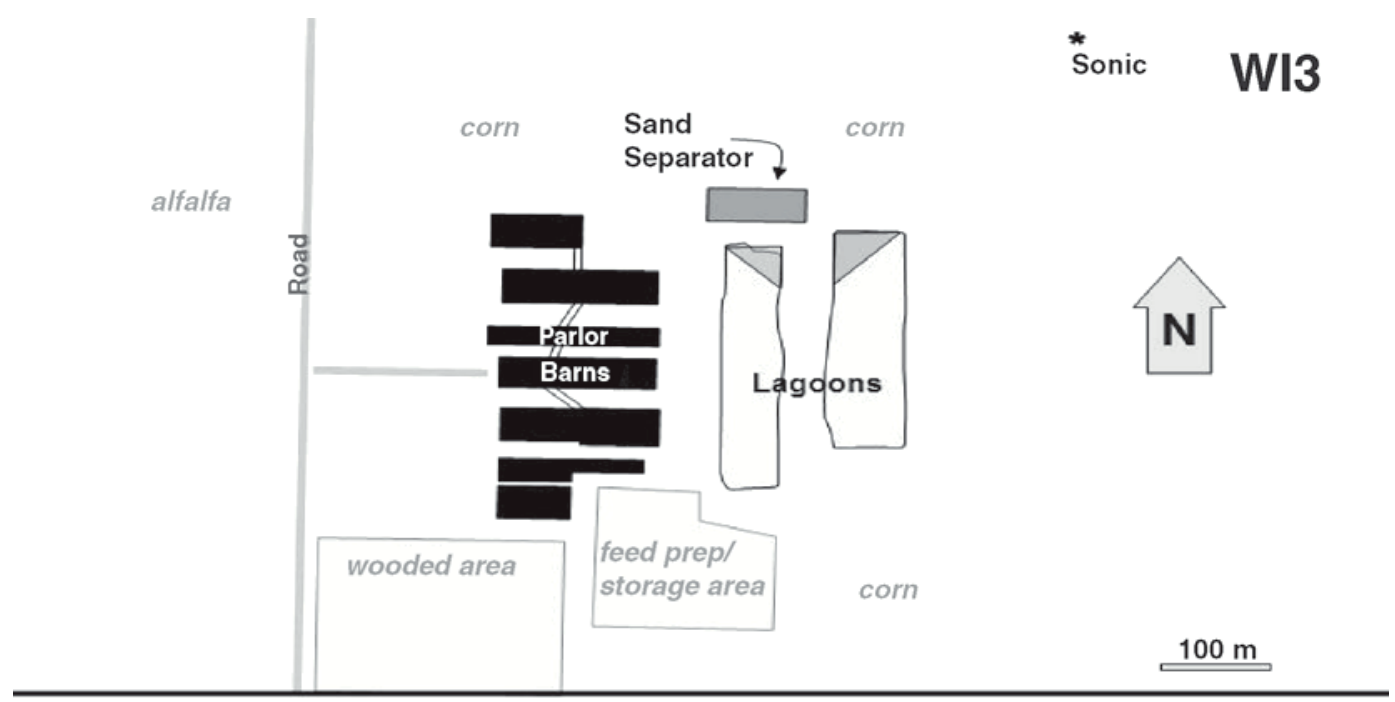

Figure 3. Layout of farm WI3. Surrounding terrain was rolling with no obstructions in any direction except for a wooded area and a feed preparation/storage area to the south of the barns and lagoons. 
Upwind concentrations were always $<0.010 \mathrm{ppm}_{\mathrm{v}}$ with measured average background concentrations of 0.000 , 0.010 , and $0.005 \mathrm{ppm}_{\mathrm{v}}$ for winter, summer, and autumn, respectively, which were used as background concentrations $\left(C_{\mathrm{b}}\right)$. Laser signals were processed to give 15-min mean concentrations along the laser line $\left(C_{\mathrm{L}}\right)$. Mixingratio concentrations $\left(\mathrm{ppm}_{\mathrm{v}}\right)$ were converted to absolute concentrations $\left(\mathrm{g} / \mathrm{m}^{3}\right)$ using the air temperature for each period and the mean atmospheric pressure for each farm's elevation. The lasers were calibrated onsite using calibration tubes flooded with $\mathrm{NH}_{3}$ gas standards.

Three-dimensional sonic anemometers (CSAT-3, Campbell Sci., Logan, UT) were located nearby the farm in representative vegetation for whole-farm measurements and over the lagoon surface for lagoon measurements. They provided the meteorological information for our dispersion calculations [i.e., time-series of friction velocity $\left(u_{*}\right)$; Monin-Obukhov stability length $(L)$; roughness length $\left(z_{0}\right)$; average acoustic air temperature $(T)$; and the average wind direction $(\beta)]$. The anemometers also provided velocity standard deviations $\left(\sigma_{\mathrm{u}, \mathrm{v}, \mathrm{w}}\right)$ used in our dispersion calculations. Technique development and data requirements for these procedures have been discussed previously (Flesch et al., 2004); an additional discussion of calculations and data analysis for these specific studies has been described in a companion report (Flesch et al., 2009).

\section{bLS Calculations}

A bLS inverse-dispersion technique was used to determine farm emissions. In this technique, one models the dispersion of a target gas from an emission source to a downwind location, enabling a downwind concentration measurement to establish the emission rate. The technique depends on an accurate calculation of dispersion from the source to the measurement location. We used the commercially available software WindTrax (Thunder Beach Scientific, Nanaimo, Canada), which combines an interface where sources and sensors are mapped with the bLS dispersion model described by Flesch et al. (2004), for this purpose.

The bLS calculation treats farms as idealized emission sources (i.e., exposed to an idealized wind environment and having a simplified spatial emission pattern) [Note: The bLS model assumes an idealized atmosphere where the near-ground wind properties are described by Monin-Obukhov similarity theory (see Garratt, 1992) with average wind and turbulence statistics defined by the friction velocity $u_{*}$, the Obukhov stability length $L$, the surface roughness length $z_{0}$, and the wind direction $\beta$, parameters determined from 3 -dimensional sonic anemometry.] Commercial dairy farms (Figures 1, 2, and 3) will not meet these assumptions when considered in detail, but Flesch et al. (2009) describe the broad requirements for applying an idealized bLS calculation to estimate emissions from nonideal sites and discuss in detail the strategy used to calculate emissions at these specific study farms. In summary, lasers were placed downwind of the various farm source components or downwind of the whole farm, with anemometers positioned to measure the wind conditions experienced by source material traveling to the laser detector. The bLS model then calculates the relationship between the concentration and the emission rate for the prevailing wind conditions, so that a 15-min time-series of the emission rate is given by the corresponding time-series of downwind concentration (and winds). Flesch et al. (2009) also describe criteria of defining good observation periods based on having good wind conditions for a calculation. Measurement conditions in which dispersion models are error prone include light winds and extreme stabilities; similarly, measurements are inappropriate when the wind direction does not place the laser path within a representative section of the source plume. Measurements were not used when prevailing weather conditions were not suitable for quantifying emissions.

More usable data are generally obtained during daytime because of light winds or highly stable conditions that occur frequently during nighttime. Because of the diurnal pattern of $\mathrm{NH}_{3}$ emissions, a biased daily estimate would be obtained if one used the ensemble mean of all estimates; therefore, a strategy that calculated the diurnal 2-h mean of usable emission estimates over the study period was first calculated. Then, the 2-h means were used to determine a daily emission rate.

\section{Emissions Comparisons}

Gas recovery is defined as the percentage of the mean ratio of bLS-calculated emissions to actual emissions (i.e., $\mathrm{Q}_{\mathrm{bLS}} / \mathrm{Q}_{\mathrm{actual}} \times 100$, where $\mathrm{Q}$ is the emission rate). This type of study is not amenable to probability analysis but for comparison analysis we determined an assumed estimate of uncertainty from measurement differences between $\mathrm{Q}_{\mathrm{bLS}} / \mathrm{Q}_{\text {tracer }}$ studies (see Appendix for the list of tracer studies used to evaluate our estimate of uncertainty). The actual error is $100.1 \%$ across all studies with a standard error of $2.2 \%$ between all studies. The average error of recovery within each study was $19.1 \%$ with a standard error of the variations of $1.6 \%$ (the period-to-period variability within each study is due to the uncertainties in the bLS dispersion calculations, in the concentration sensors, and in the wind sensors). Based on these studies we use an estimate of uncertainty or accuracy of $100 \pm 20 \%$ for comparison analysis between sites and periods or any other 


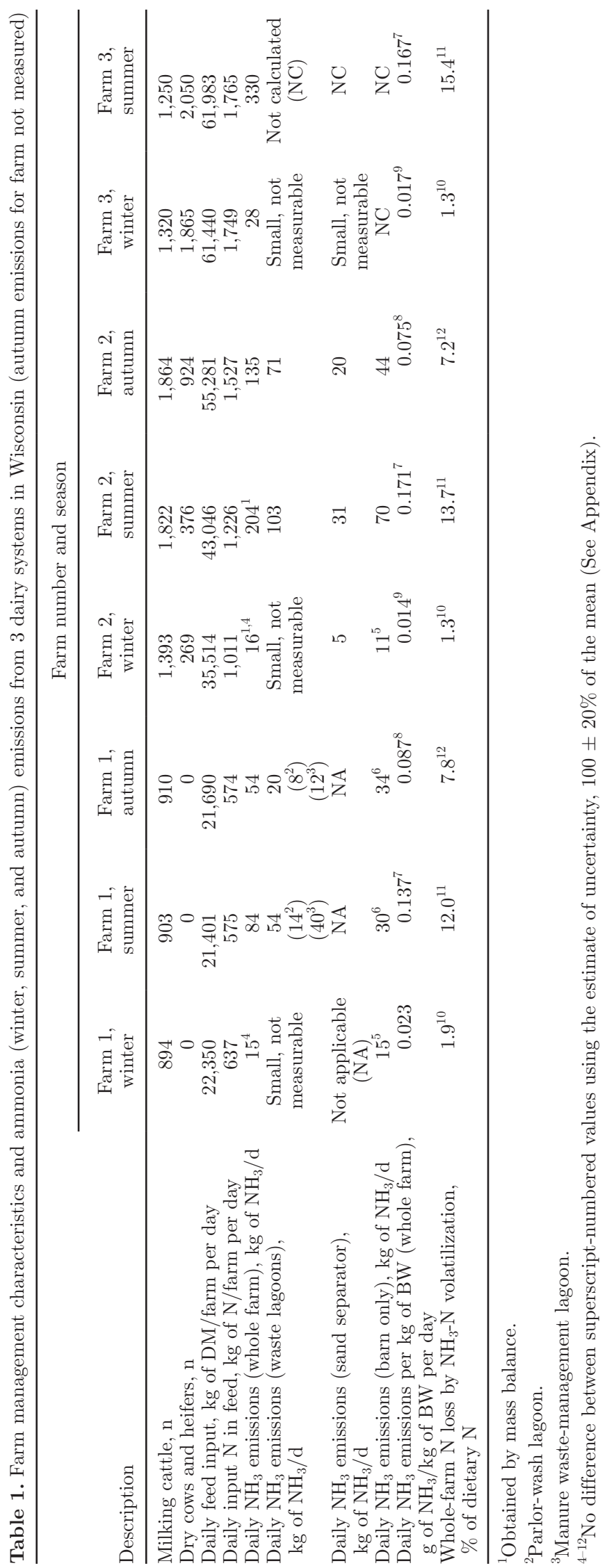

needed comparison of difference. When compared with emissions determined by the integrated horizontal flux technique, there was no difference between the emission rates.

\section{RESULTS AND DISCUSSION}

Table 1 gives farm characteristics (number of animal types), daily feed intake of $\mathrm{DM}$ and $\mathrm{N}$, and mean $\mathrm{NH}_{3}$ emission rates $\left(\mathrm{kg}\right.$ of $\mathrm{NH}_{3} / \mathrm{d}$ ) for the whole farm, and for component sources of $\mathrm{NH}_{3}$ (barns, sand separators, and lagoons) for all 3 farms studied over all 3 seasons. Whole-farm emission rates also are presented on an animal BW basis (g of $\mathrm{NH}_{3} / \mathrm{kg}$ of BW per day) and as a percentage of dietary $\mathrm{N}$ input to the farm (\%).

\section{Diurnal Emissions}

Average seasonal diurnal $\mathrm{NH}_{3}$ emissions are presented in Figure 4 for winter and summer (autumn data not shown). These emission curves are created from hundreds of 15-min observations taken over many days, and 2-h averages across the data collection period were used to develop the seasonal daily curve to avoid time-of-day bias (typically, fewer data are obtained at night than during the day). Comparison between winter emissions suggests that there was little difference in emissions between farms (see also Table 1) and throughout the day. Summertime emissions show that emission rates increased, as would be expected, as the size of farm increased. Diurnal autumn emissions (WI3 not measured) were intermediate between winter and summer emissions. Midday emissions during summer and autumn (autumn not shown for WI3) were about twice the nighttime emissions because of increased daytime temperature and windflow. This diurnal pattern extended to all $\mathrm{NH}_{3}$ emission components, including barns, lagoons, and sand separators (Flesch et al., 2009), reflecting daytime increases in temperature and wind speed, which affect emission rates.

\section{Barn $\mathrm{NH}_{3}$ Emissions}

Figure 5 presents the component emissions for farms WI1 (A) and WI2 (B) during the 3 measurement seasons (WI3 components were not separated out). Barn emissions during winter comprised the majority of emissions because no measurable emissions were found from the lagoons and only small emissions (not accurately measurable) were found from the sand separators (where measured). As seasonal temperatures increased, (winter $<$ autumn $<$ summer), the proportion of total farm emissions derived from dairy barns became smaller, thereby reflecting the influence of temperature and 


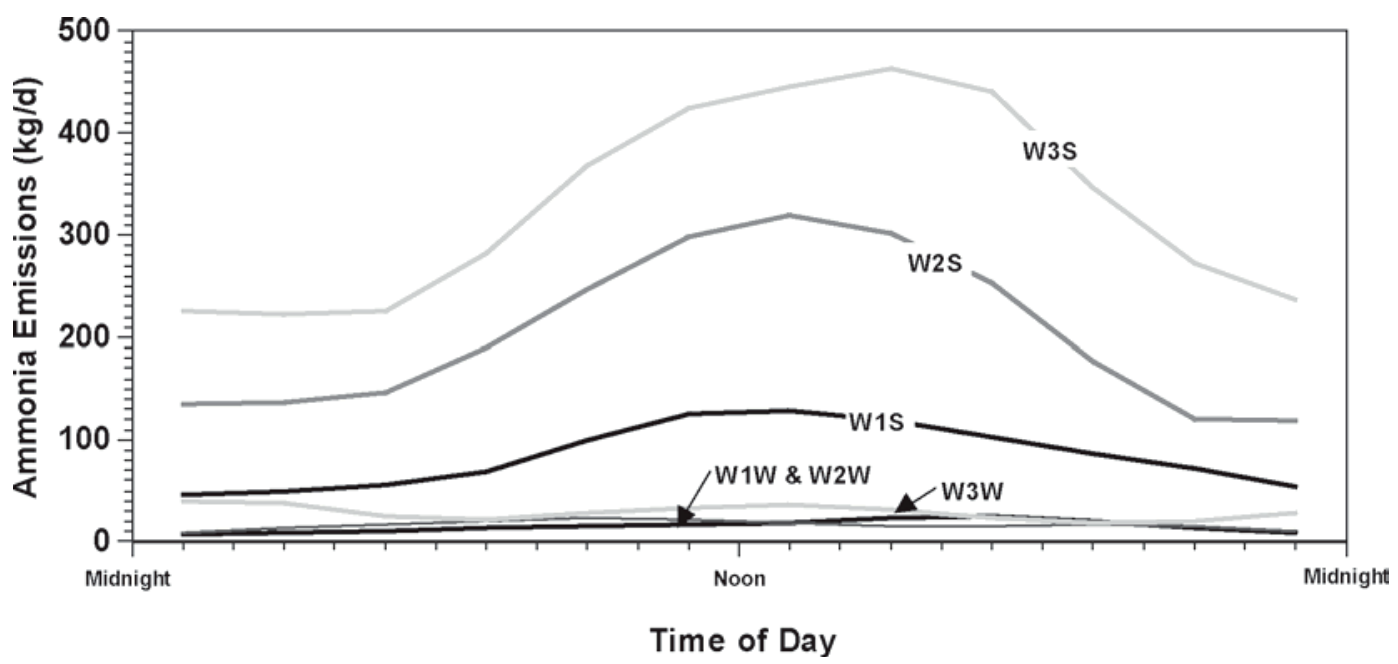

Figure 4. Winter and summer average seasonal $\mathrm{NH}_{3}$ emissions for 3 dairy farms in Wisconsin (Note: W1W = farm WI1 in winter; W1S = farm WI1 in summer; W2W = farm WI2 in winter; W2S = farm WI2 in summer; W3W = farm WI3 in winter; W3S = farm WI3 in summer).

wind speed on emissions from the waste-management system (Harper, 2005).

\section{Waste-Management Emissions}

During winter, lagoon emissions were small and not measurable, agreeing with previous studies showing that $\mathrm{NH}_{3}$ emissions cease below a water temperature of about $3^{\circ} \mathrm{C}$ (Harper et al., 2000; 2004; Rumburg et al., 2006). Indeed, the surfaces of lagoons for all farms were predominantly frozen during winter; however, an exception occurred at farm WI3, where lagoon pumping exposed a small portion of liquid surface. Thus, we assumed that winter emissions are only from the barns and the sand separator (if present).

During summer and autumn at farms WI1 and WI2, emissions were obtained individually for each of the lagoons. The configuration of housing and lagoons at

A

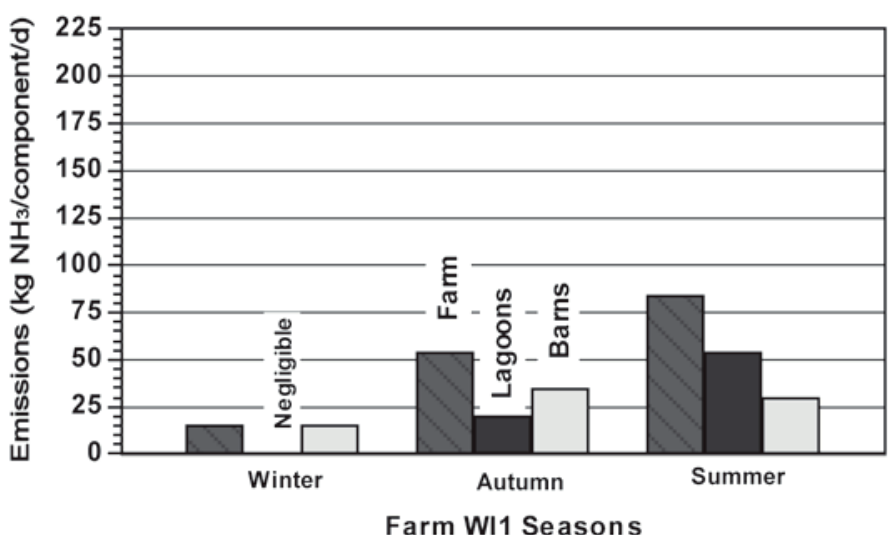

farm WI3 was such that the individual $\mathrm{NH}_{3}$ sources could not be separated. During summer at farm WI1 (Figure 1), the parlor wastewater lagoon was mostly wash water from milking operations and contained minimal manure and urine. The $\mathrm{NH}_{4}^{+}$concentration in the housing lagoon was much greater (6.8 vs. $1.5 \%$ $\mathrm{N})$ resulting in concomitant $\mathrm{NH}_{3}$ emissions from the housing lagoon that were about 3 times greater than that observed from the parlor lagoon (Table 1). During autumn, the parlor and housing lagoons were similar in concentration (2.6 vs. $2.8 \% \mathrm{~N}$ ) providing similar emission rates. The emission rates for lagoons during autumn were much lower than during summer. This was due primarily to lagoon temperature and its effect on percentage of $\mathrm{NH}_{3}$ in solution (Harper, 2005). Ammonium concentrations in the west and east lagoons of WI2 were the same but total emissions were larger in the west lagoon because it was much larger in surface

B

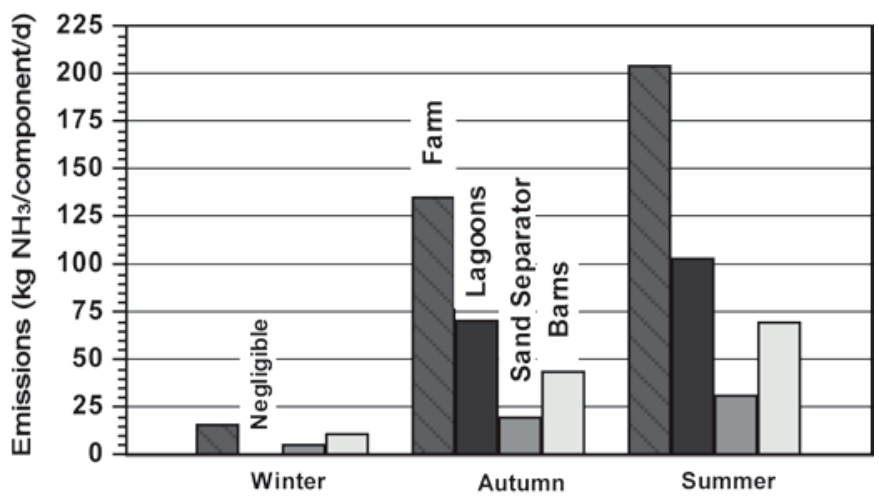

Farm WI2 Seasons

Figure 5. Farm component emissions for farms WI1 (A) and WI2 (B) (see Table 1 for animal numbers). 
area. At WI1 and WI2, the lagoons and sand separators were responsible for about two-thirds of the total farm $\mathrm{NH}_{3}$ emissions with the remaining emissions originating from the barns.

Waste-management emissions from WI2 during winter were all from the sand separator because the lagoons were frozen. With the barns mostly closed, the sand separator $\mathrm{NH}_{3}$ emissions during winter were about one-third of the total farm emissions. During summer and autumn, the largest percentage of $\mathrm{NH}_{3}$ emissions from WI2 were associated with the lagoons (about half), with some emissions from the sand separators. The sand separator at WI2 is about $20 \%$ of the lagoon surface area and the emissions are about the same proportion of the total waste-management $\mathrm{NH}_{3}$ emissions (about 22\%). Emissions from the sand separator increased with increasing seasonal temperature reflecting the physical chemistry of temperature on the system (Harper, 2005).

\section{Whole-Farm Emissions}

There was large variability (Table 1) in the daily $\mathrm{NH}_{3}$ emission rates among farms and seasons during the study, ranging from $15 \mathrm{~kg}$ (WI1 in winter) to 330 $\mathrm{kg}$ of $\mathrm{NH}_{3} / \mathrm{d}$ (WI3 in summer); the variability in daily emission rate varies largely as a function of farm size (number of animals) and season. When emissions were expressed on a per-animal BW basis, there was similarity across the 3 farms within seasons. Winter emissions from the farms ranged from 0.014 to $0.023 \mathrm{~g}$ of $\mathrm{NH}_{3} /$ $\mathrm{kg}$ of BW per day, increasing to 0.137 to $0.171 \mathrm{~g}$ of $\mathrm{NH}_{3} / \mathrm{kg}$ of BW per day in summer, with autumn values being intermediate. Comparison of emissions as a percentage of dietary $\mathrm{N}$ input to the farms also showed similar within-season emissions between the farms, but similarly large seasonal differences. In general, summer emissions were an order of magnitude greater than winter emissions with the autumn rate about half the summer emission rates.

Whole-farm emissions ( $\mathrm{kg}$ of $\mathrm{NH}_{3}$ /farm per day) for farm WI1 were about 5 times greater (Figure 6A) during summer than winter (with autumn emissions intermediate between the climatic extremes), and for farms WI2 and WI3, whole-farm emissions were 13 and 12 times greater in summer than in winter, respectively, reflecting the effect of seasons on emissions. There was no difference in relative emissions between farms (as a percentage of dietary N; Table 1 and Figure 6B) within seasons for winter and autumn. For summer, there was no relative difference between WI2 and either WI1 or WI3 for $\mathrm{NH}_{3}-\mathrm{N}$ loss expressed as percentage of dietary $\mathrm{N}$ input; however, there was a significant but small difference between WI1 and WI3. During winter, relative emissions on a BW basis (Table 1) were slightly larger at WI1, possibly because of unusually warm temperatures during the measurement period. There were no differences between the farms measured within seasons during autumn or summer (autumn emissions were not measured at WI3).

Data were collected during representative periods of minimum (winter), maximum (summer), and transitional (autumn) temperatures because annual continuous measurements are prohibitively expensive. Previous studies in other CAFO industries using 3 seasons of measurements have shown that transitional seasons give intermediate emission rates between winter and summer (Harper et al., 2004) as in these studies. Use of the transitional season rates did not significantly improve annual average estimates compared with using just summer and winter emissions. Consequently, annual averages could be computed as the average of summer and winter rates.

These studies suggest that average annual dairy emissions from modern, intermediate-to-large freestalltype dairy systems in Wisconsin are $7.6 \pm 1.5 \%$ of feed $\mathrm{N}$ emitted as $\mathrm{NH}_{3}-\mathrm{N}$. Individually, the 3 farms were similar at 7.0, 7.5, and $8.4 \%$ of input feed $\mathrm{N}$ for WI1, WI2, and WI3, respectively. Average seasonal emissions across all farms were $1.5,7.5$, and $13.7 \%$ of feed $\mathrm{N}$ for winter, autumn, and summer, respectively.

\section{Barn $\mathrm{NH}_{3}$ Concentrations}

Ammonia concentrations in the barns were measured for several days at a height of $0.5 \mathrm{~m}$ above the animals' heads (about $2.5 \mathrm{~m}$ from floor level) and spanning the full length of a barn. Figure 7, for example, gives $\mathrm{NH}_{3}$ concentrations over $3 \mathrm{~d}$ that ranged from $<1 \mathrm{ppm}$ to about $5 \mathrm{ppm}_{\mathrm{v}}$ during winter when the barns were closed. These concentrations are much lower than those found in other CAFO (Harper et al., 2004), presumably because of the much larger air exchange rates in dairy barns, even in winter. Concentrations in the barns during summer were very low because there was little restriction to airflow through the barns, thereby allowing $\mathrm{NH}_{3}$ to dissipate. The measured $\mathrm{NH}_{3}$ concentrations within the barns do not constitute an animal or human health hazard throughout the year because the levels are below the Occupational Safety and Health Administration (OSHA) and National Institute for Occupational Safety and Health (NIOSH) 8-h exposure levels (50 and $25 \mathrm{ppm}$, respectively).

\section{Emissions Models}

Figure 8 gives emissions relationships between the mean annual $\mathrm{NH}_{3}$ daily emission rate with respect to 


\section{A}

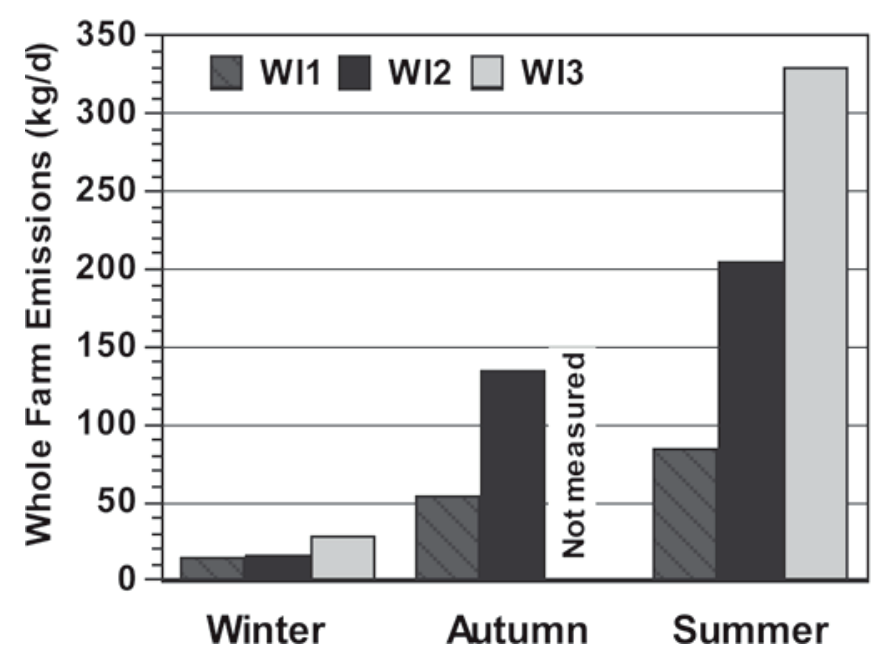

B

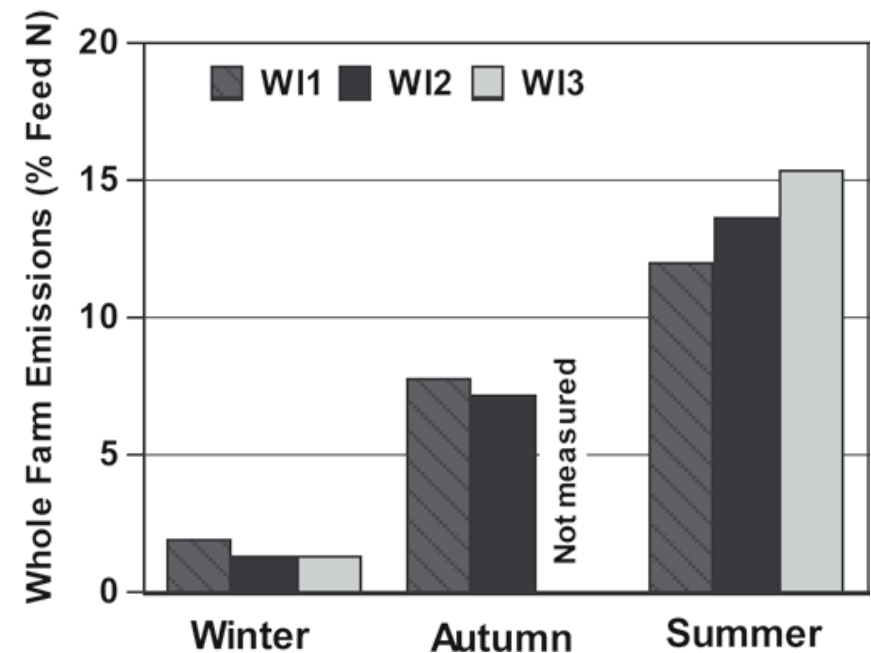

Figure 6. Ammonia emissions by dairy size and season on a (A) whole-farm emissions and (B) percentage feed $\mathrm{N}$ basis.

the number of animals per farm (panel A) and the total farm dietary feed $\mathrm{N}$ input (panel B). These data represent data collected from 3 different farms for 3 seasons with data collection $24 \mathrm{~h} / \mathrm{d}$ for 10 to $14 \mathrm{~d}$ each season. For these freestall-type barns and lagoon management operations, selection of measured dairy sizes provided the capability to predict annual-average emissions for other farms of this type in Wisconsin. These figures indicate that the farms were very similar in management and that an increase in size of dairy operations did not change relative unit (animal numbers or feed $\mathrm{N}$ input) emissions rates. Prediction of average annual emissions is closely related to animal numbers $(y=-1.18+0.056$ $\left.\times x, \mathrm{r}^{2}=0.997\right)$ and farm input feed $\mathrm{N}(y=0.0062 \times$ $\left.x^{1.4}, \mathrm{r}^{2}=0.948\right)$.

\section{Comparison with Other Studies and Estimates}

Recent estimates calculated from USEPA (2004, Tables $3-6$ and 3-7) suggest that an annual mean of

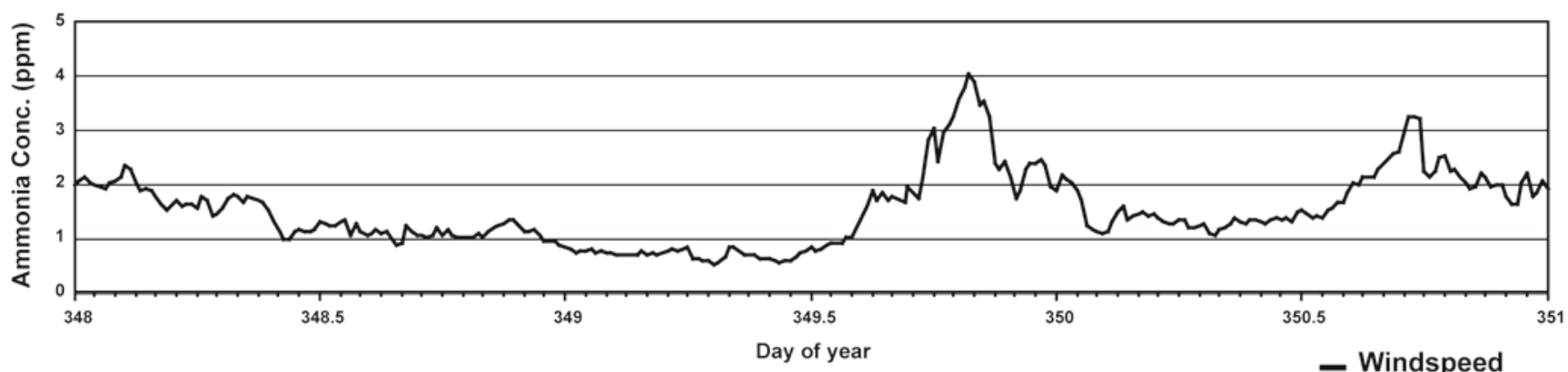

- T ambient

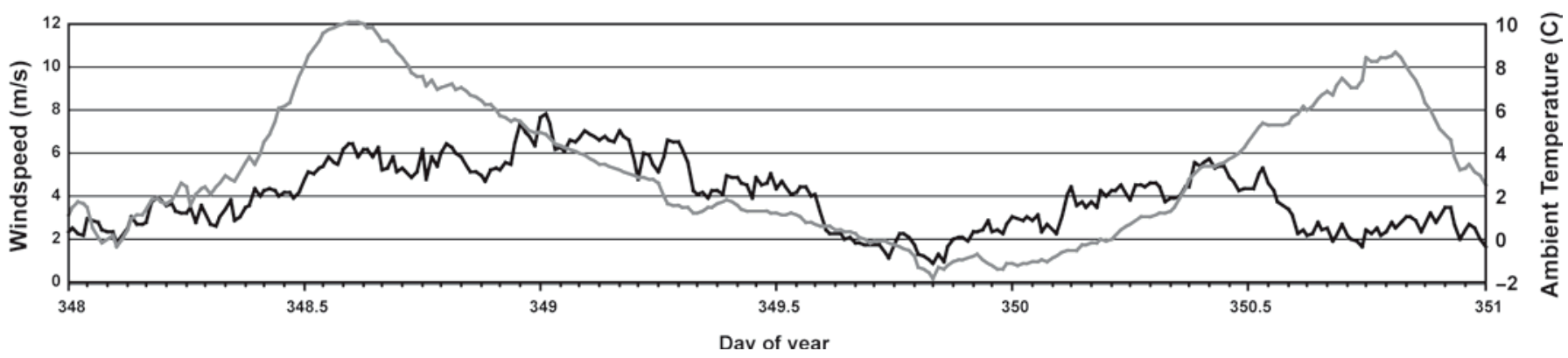

Figure 7. Ammonia concentrations at $0.5 \mathrm{~m}$ above the animals' heads (about $2.0 \mathrm{~m}$ from floor level) in a freestall dairy barn along with ambient wind speed and temperature at farm WI1 during winter. 

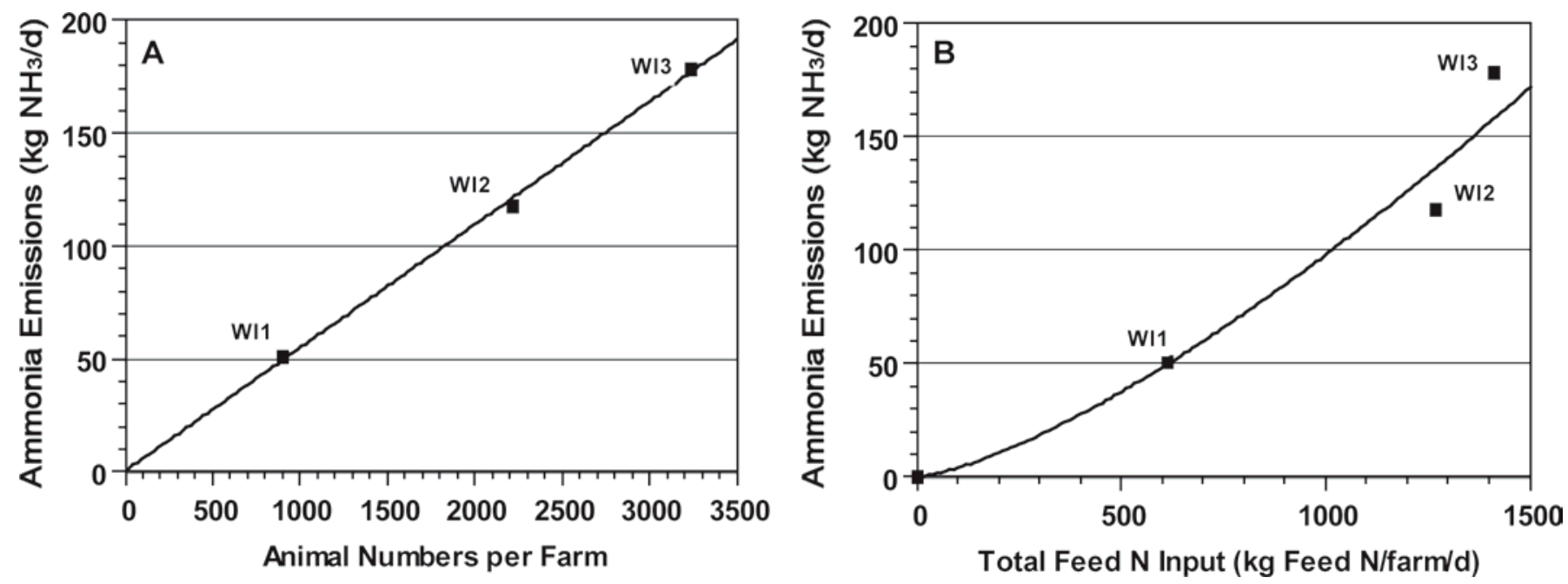

Figure 8. Whole-farm (barns and waste-management excluding field applications) emissions from Wisconsin dairies in relation to (A) animal numbers per farm $\left[y=-1.18+0.056 \times x, \mathrm{r}^{2}=0.997\right]$ and $(\mathrm{B})$ total feed input $\left[y=0.0062 \times x^{1.4}, \mathrm{r}^{2}=0.948\right]$. These are the average annual emission rates from 3 different-sized, geographically dispersed, freestall-type dairies in Wisconsin.

$11 \%$ (no stated error limits) of input feed $\mathrm{N}$ is emitted as $\mathrm{NH}_{3}$ from this type of dairy housing (scraped barns) and $18 \%$ is emitted from waste-management lagoons. These emissions represent a total of $29 \%$ of input feed $\mathrm{N}$ emitted as volatilized $\mathrm{NH}_{3}$, which is significantly larger than the average $7.6 \pm 1.5 \%$ emissions determined in these studies.

Studies in a small, experimental dairy farm (Rumburg et al., 2008a,b) found annual emissions of $11 \%$ of input feed $\mathrm{N}$ from freestall barns and 15\% from the waste-management system associated with the experimental dairy operation. The total emissions of $26 \%$ were about 4 times larger than emissions found on commercial farms in Wisconsin. Chamber studies on $\mathrm{NH}_{3}$ emissions from simulated dairy production (J. M. Powell; unpublished data), which are not representative of whole-farm winter or summer conditions, have shown emission rates of about $50 \mathrm{~g}$ of $\mathrm{NH}_{3}$ /animal per day, which is not different from our annual average of $55 \pm 11 \mathrm{~g}$ of $\mathrm{NH}_{3}$ /animal per day for all farms and all seasons combined. Flesch et al. (2009) compared dairy individual component emissions (e.g., lagoons, barns) with those of others (McGinn et al., 2006; Powell et al., 2008b) and, considering potential climatic, management, and other differences between the studies, found the rates to be surprisingly similar.

Studies by Rumburg et al. (2006) conclude that $28 \%$ of applied lagoon slurry was volatilized - a value close to the USEPA (2004) estimate of 20 to $24 \%$ of applied $\mathrm{N}$ lost as $\mathrm{NH}_{3}-\mathrm{N}$ volatilization from land spreading of liquid lagoon manure (a dairy emission component that we did not measure). Further studies are planned to evaluate $\mathrm{N}$ lost as $\mathrm{NH}_{3}$ in this manner.
These Wisconsin dairy emissions are considerably less than the annual average of $46 \pm 9 \%$ [L. A. Harper, T. K. Flesch, W. N. Todd (USDA-ARS, Bushland, TX), A. Cole (USDA-ARS, Bushland, TX), R. R. Sharpe (ret.; USDA-ARS, Watkinsville, GA), and J. D. Wilson (Earth and Atmospheric Sciences, University of Alberta, Edmonton, Canada); unpublished data], 39\% (Todd et al., 2007), and 53\% (Todd et al., 2008) of input feed N reported for cattle feedlots in Texas. The average $7.6 \%$ emissions from these 3 dairies over 3 seasons is also somewhat less than the $14.8 \%$ of feed $\mathrm{N}$ emissions rate reported from swine production (Harper et al., 2004).

The agreement between whole-farm emissions measured at our 3 study farms is encouraging. This, together with a nominal agreement between our barn and lagoon emission rates and those in several other studies, provides an indication that the inverse-dispersion technique and our measurement strategy provide accurate emission measurements.

\section{CONCLUSIONS}

This study used the bLS inverse-dispersion technique to estimate whole-farm $\mathrm{NH}_{3}$ emissions from dairy operations. Over the course of our study we found daily emission rates from the farms ranging from 15 to 330 $\mathrm{kg}$ of $\mathrm{NH}_{3} /$ farm per day, depending on the number of animals, input feed $\mathrm{N}$, season, and climatic conditions. Relative emissions between the farms during winter were similar, all less than $2 \%$ of input feed N. Relative emissions between farms during summer were also similar, ranging from about 12 to $15 \%$ of input feed N. Autumn emission magnitudes were intermediate between sum- 
mer and winter emissions on all farms measured. There were no significant differences (on a unit basis) between farms within each of the seasons; however, there were large differences between seasons for the farms, being from 6 to 13 times greater in summer than in winter. Average annual $\mathrm{NH}_{3}$ emissions, in relation to animal numbers and input feed $\mathrm{N}$, were linearly related with the size of the operations, indicating that for these types of freestall barns and waste-management systems throughout Wisconsin, size of operation did not affect emission rates on a unit basis. Average annual emissions from barns and manure treatment and storage for all farms were $7.6 \pm 1.5 \%$ of input feed N. These annual $\mathrm{NH}_{3}$ emissions are considerably smaller than currently used USEPA estimates for dairy emissions and significantly smaller than emissions from other types of animal feeding operations.

\section{ACKNOWLEDGMENTS}

This work has been supported by USDA-ARS Specific Cooperative Agreement Project Numbers 3655-12630001-02S and 58-3655-6-F157 between the Dairy Forage Research Center, USDA-ARS (Madison, WI) and the University of Georgia (Athens) and University of Alberta (Edmonton, Canada), respectively. Appreciation is particularly extended to the host farm owners and managers for their assistance in providing the facility and for needed input management data. Thanks are extended to Steve Struss (Department of Agriculture, Trade and Consumer Protection, Madison, WI) and David Grande (Department of Natural Resources, Madison, WI) for their assistance in obtaining suitable farms for measurement. Gratitude is extended for the conscientious assistance in the field by technical assistant Robbin Smith (USDA-ARS, Madison, WI).

\section{REFERENCES}

Anonymous. 2008. Wisconsin Climate. http://www.city-data.com/ states/Wisconsin-Climate.html Accessed Aug. 8, 2008.

Asman, W. A. H., P. Cellier, S. Genermont, N. J. Hutchins, and S. G. Sommer. 1998. Ammonia emission research: From emission factors to process descriptions. EUROTRAC Newsl. 20:2-10.

Bouwman, A. F., D. S. Lee, W. A. H. Asman, F. J. Dentener, K. W. Van Der Hoek, and J. G. J. Oliver. 1997. A global high-resolution emission inventory for ammonia. Global Biogeochem. Cycles 11:561-587.

Eklund, B., and J. LaCosse. 1995. Field measurements of greenhouse gas emissions from the wastewater treatment systems at 2 farms. EPA Contract No. 68-D1-0031, Work Assignment 66. Radian Corp. Report to US Environmental Protection Agency, Research Triangle Park, NC.

Flesch, T. K., L. A. Harper, J. M. Powell, and J. D. Wilson. 2009. Use of dispersion analysis for measurement of ammonia emissions from Wisconsin dairy farms. Agric. Eng. 52:253-265.

Flesch, T. K., and J. D. Wilson. 2005. Estimating trader emissions with a backward Lagrangian stochastic technique. Pages 513-531 in Micrometeorological Measurements in Agricultural Systems. J.
L. Hatfield and J. M. Baker, ed. Agron. Monogr. 47. ASA, CSSA, and SSSA, Madison WI.

Flesch, T. K., J. D. Wilson, and L. A. Harper. 2005a. Deducing groundair emissions from observed trace gas concentrations: A field trial with wind disturbance. J. Appl. Meteorol. 44:475-484.

Flesch, T. K., J. D. Wilson, L. A. Harper, and B. P. Crenna. 2005b. Estimating gas emission from a farm using an inverse-dispersion technique. Atmos. Environ. 39:4863-4874.

Flesch, T. K., J. D. Wilson, L. A. Harper, B. P. Crenna, and R. R. Sharpe. 2004. Deducing ground-air emissions from observed trace gas concentrations: A field trial. J. Appl. Meteorol. 43:487-502.

Gao, Z., R. L. Desjardins, and T. K. Flesch. 2008. Comparison of a simplified micrometeorological mass difference technique and an inverse dispersion technique for estimating methane emissions from small area sources. Agric. For. Meteorol. 149:891-898

Garratt, J. R. 1992. The Atmospheric Boundary Layer. Cambridge University Press, New York, NY.

Harper, L. A. 2005. Ammonia: Measurement Issues. Pages 345-379 in Micrometeorological Measurements in Agricultural Systems. J. L. Hatfield and J. M. Baker, ed. Agron. Monogr. 47. ASA, CSSA, and SSSA, Madison WI.

Harper, L. A., T. K. Flesch, R. L. Desjardins, G. Zhiling, and M. McBain. 2006. Backward Lagrangian dispersion analysis for determination of multiple emission sources. Prelim. Rep. to Agriculture and Agri-Food Canada, Ottawa, Ontario, Canada.

Harper, L. A., R. R. Sharpe, and T. B. Parkin. 2000. Gaseous emissions from anaerobic swine lagoons: Ammonia, nitrous oxide, and dinitrogen gas. J. Environ. Qual. 29:1356-1365.

Harper, L. A., R. R. Sharpe, T. B. Parkin, A. De Visscher, O. van Cleemput, and F. M. Byers. 2004. Nitrogen cycling in swine production systems: Ammonia, nitrous oxide, and dinitrogen gas emissions. J. Environ. Qual. 33:1189-1201.

Laubach, J., and F. M. Kelliher. 2005. Methane emissions from dairy cows: Comparing open-path laser measurements to profile-base techniques. Agric. For. Meteorol. 135:340-345.

McBain, M. C., and R. L. Desjardins. 2005. The evaluation of a backward Lagrangian stochastic (bLS) model to estimate greenhouse gas emissions from agricultural sources using a synthetic tracer gas. Agric. For. Meteorol. 135:61-72.

McGinn, S. M., T. K. Flesch, L. A. Harper, and K. A. Beauchemin. 2006. An approach for measuring methane emissions from whole farms. J. Environ. Qual. 35:14-20.

Peters, J., S. M. Combs, B. Hoskins, J. Jarman, J. L. Kovar, M. E. Watson, A. M. Wolf, and N. Wolf. 2003. Recommended Methods of Manure Analyses. University of Wisconsin Cooperative Extension Publication A3769. Madison WI. http://cecommerce.uwex.edu/ pdfs/A3769.PDF Accessed Aug. 21, 2008.

Powell, J. M., G. A. Broderick, and T. H. Misselbrook. 2008a. Seasonal diet affects ammonia emissions from tie-stall dairy barns. J. Dairy Sci. 91:857-869.

Powell, J. M., D. B. Jackson-Smith, D. F. McCrory, H. Saam, and M. Mariola. 2006. Validation of feed and manure data collected on Wisconsin dairy farms. J. Dairy Sci. 89:2268-2278.

Powell, J. M., T. H. Misselbrook, and M. D. Casler. 2008b. Season and bedding impacts on ammonia emissions from tie-stall diary barns. J. Environ. Qual. 37:7-15.

Rumburg, B., G. H. Mount, J. Filipy, B. Lamb, H. Westberg, D. Yonge, R. Kincaid, and K. Johnson. 2008a. Measurement and modeling of atmospheric flux of ammonia from dairy milking cow housing. Atmos. Environ. 42:3364-3379.

Rumburg, B., G. H. Mount, D. Yonge, B. Lamb, H. Westberg, J Filipy, J. Bays, R. Kincaid, and K. Johnson. 2006. Atmospheric flux of ammonia from sprinkler application of dairy waste. Atmos. Environ. 40:7246-7258.

Rumburg, B., G. H. Mount, D. Yonge, B. Lamb, H. Westberg, M. Neger, J. Filipy, R. Kincaid, and K. Johnson. 2008b. Measurements and modeling of atmospheric flux of ammonia from an anaerobic dairy waste lagoon. Atmos. Environ. 42:3380-3393.

Todd, R. W., N. A. Cole, R. N. Clark, T. K. Flesch, L. A. Harper, and B. H. Baek. 2008. Ammonia emissions from a beef cattle feedyard on the southern High Plains. Atmos. Env. 42:6797-6805. 
Todd, R. W., N. A. Cole, L. A. Harper, and T. K. Flesch. 2007. Fluxgradient estimates of ammonia emissions from beef cattle feedyard pens. Proc. Am. Soc. Agric. Biol. Eng., Int. Symp. Air Quality and Waste Management for Agriculture, Broomfield, CO.

USEPA (US Environmental Protection Agency). 2004. National Emission Inventory-Ammonia Emissions from Animal Husbandry Operations (Draft Report, January 30, 2004). http//www.epa. gov/ttn/chief/ap42/ch09.

\section{APPENDIX}

Table A1 provides a list of independent studies along with site characteristics and gas type used for validation of bLS technique. Gas recovery is defined as the percentage of the mean ratio of bLS calculated emissions to actual emissions (i.e., $\mathrm{Q}_{\mathrm{bLS}} / \mathrm{Q}_{\text {release }} \times 100$ ). For all studies, the average recovery was $100.1 \%$ with a standard error between all studies of $2.2 \%$. The average error of recovery within each study was $19.1 \%$ with a standard error of the variations of $1.6 \%$ (the periodto-period variability within each study is due to the uncertainties in the bLS dispersion calculations, in the concentration sensors, and in the wind sensors). We use an error (difference) of the estimation of uncertainty to be $100 \pm 20 \%$. Table A2 compares 3 studies of trace-gas emissions between the bLS and integrated horizontal flux (IHF) technologies $\left(\mathrm{Q}_{\mathrm{bLS}} / \mathrm{Q}_{\mathrm{IHF}}\right)$ and found no difference between the techniques. The IHF technique is physically straightforward and requires no correction for atmospheric stability (Harper, 2005).

Table A1. Use of tracer gases to verify emissions recoveries for backward Lagrangian stochastic analysis procedure

\begin{tabular}{lrll}
\hline Gas & Recovery $(\%)$ & Site characteristics & Reference \\
\hline $\mathrm{CH}_{4}$ & $102 \pm 22$ & Grass, no obstructions & Flesch et al. (2004) \\
$\mathrm{CH}_{4}$ & $98 \pm 20$ & Grass, obstructions & Flesch et al. (2005b) \\
$\mathrm{CH}_{4}$ & $107 \pm 13$ & Grass, no obstructions & Harper et al. (2006) \\
$\mathrm{CH}_{4}$ & $106 \pm 16$ & Grass, no obstructions & McBain and Desjardins (2005) \\
$\mathrm{CH}_{4}$ & $99 \pm 20$ & Grass, elevated source & McBain and Desjardins (2005) \\
$\mathrm{SF}_{6}$ & $100 \pm 29$ & Whole-farm, dairy & McGinn et al. (2006) \\
$\mathrm{CH}_{4}$ & $86 \pm 17$ & Whole-farm, dairy & McGinn et al. (2006) \\
$\mathrm{CH}_{4}$ & $103 \pm 16$ & Grass, no obstructions & Gao et al. (2008) \\
\hline
\end{tabular}

Table A2. Three comparison trace-gas emissions studies between the backward Lagrangian stochastic analysis and integrated horizontal flux (IHF) technologies $\left(\mathrm{Q}_{\mathrm{bLS}} / \mathrm{Q}_{\mathrm{IHF}}\right)$

\begin{tabular}{lccl}
\hline $\mathrm{CH}_{4}$ & $\begin{array}{c}\text { No difference from IHF } \\
\text { (open path laser) } \\
\mathrm{CH}_{4}\end{array}$ & Cows (enteric emissions) & Laubach and Kelliher (2005) \\
No difference from IHF & Cows (enteric emissions) & Laubach and Kelliher (2005) \\
Chemical & $\begin{array}{c}\text { No difference from IHF } \\
\text { (point measurement) }\end{array}$ & Short grass & Flesch and Wilson (2005) \\
\hline
\end{tabular}

